\title{
Legal Aspects of Coral Reef Management and Conservation in Bangladesh
}

\author{
Khan Md. Arman Shovon', Mohammad Abdul Hannan'2, Md. Redwanur Rahman' \\ ${ }^{1}$ Institute of Environmental Science, University of Rajshahi, Rajshahi, Bangladesh \\ ${ }^{2}$ Department of Law, University of Rajshahi, Rajshahi, Bangladesh \\ Email: shovon.arman@gmail.com, mahannan.law@ru.ac.bd
}

How to cite this paper: Shovon, K.Md.A., Hannan, M.A. and Rahman, Md.R. (2021) Legal Aspects of Coral Reef Management and Conservation in Bangladesh. Open Access Library Journal, 8: e7775. https://doi.org/10.4236/oalib.1107775

Received: July 20, 2021

Accepted: August 14, 2021

Published: August 17, 2021

Copyright $\odot 2021$ by author(s) and Open Access Library Inc.

This work is licensed under the Creative Commons Attribution International License (CC BY 4.0).

http://creativecommons.org/licenses/by/4.0/ (c) (i) Open Access

\begin{abstract}
Coral reefs remain some of the largest distinct ecosystem in the nature. In Bangladesh, coral reef grows thoroughly in the north-east region of the Bay of Bengal in Saint Martin Island. In Saint Martin Island near about 66 types of coral species are found. Coral reefs are significant for many different reasons aside from supposedly containing the most diverse ecosystems on the Earth. Coral reefs protect coastlines in many ways such as damaging effects of wave action, tropical storms, provide habitats and shelter for many marine organisms. Coral reefs are the dominant source of nitrogen and other essential nutrients for marine food chains. The Government of Bangladesh has declared eight (8) areas as Ecological Critical Areas (ECA) in 1999 and Saint Martin Island is one of them. Over-exploitation, huge tourist pressure and Illegal structures including hotels and resorts are biggest threat for the biodiversity of coral reefs. Bangladesh has already adopted many environmental laws and also part of many international environmental treaty and conventions. Coral reefs of Bangladesh are destroying day by day and there are no specific laws for protection of coral reefs. Globally there are many specific rules and regulations for protecting coral reefs. Legal framework on protecting coral reefs of Bangladesh is very much needy. A sound coral reef performs as a receiver of carbon dioxide $\left(\mathrm{CO}_{2}\right)$ gas which is the main culprit behind global warming. Furthermore, coral reef plays a great role in fighting against the greenhouse effect which is a burning issue of the present world. Bangladesh should take measures to improve enforcement of various environmental laws especially on marine environment, including adopting a revised policy on pollution prevention, developing a policy on prosecution to adopting a cooperative approach to execution of the Legal framework on protecting coral reefs of Ban-
\end{abstract}


gladesh. Bangladesh may positively draw lessons from the global laws in these areas.

\section{Subject Areas}

Environmental Law

\section{Keywords}

Coral Reefs, Waste Pollution, Environmental Law, Bangladesh, Blue Economy, Marine Resources

\section{Introduction}

The coral reef ecosystem supports some of the most bio-diverse ecosystems on the Earth. It maintains a habitat for aquatic ecosystems, and protects coastlines against erosion and natural calamities. Coral reefs are home to a range of species in marine biodiversity. Millions of people depend on coral reefs for their subsistence and employment, still these significant resources are in great crisis today. Fisheries and coral reefs-related activities remain the mainstay of livelihoods for the majority of people on St. Martin's Island [1]. While some diversification into tourist related activities during the relatively limited tourist season has benefited some local people but fisheries is still the mainstay of the local economy. According to UNEP report coral reefs are very important to the world fisheries; it can yield around fifteen (15) tons of fish and other sea food per square kilometer each year. Unfortunately, 27 per cent of the world's coral reefs have been lost and it is estimated that another fourteen per cent will be destroyed in the next ten to twenty years [2]. In Bangladesh, coral reef grows thoroughly in the north-east region of the Bay of Bengal in Saint Martin Island shown in Figure 1. Current legal framework towards conservation of coral reefs is mostly inadequate in Bangladesh [3]. Nevertheless, the international community has already begun to identify the disaster in the last decade; the efforts have not had any effect to stave off the large-scale loss of coral reefs. Based on the results of the World Ocean Conference (WOC) in Manado 2009 embodied in the Coral Triangle Initiative (CTI), obligations were established for countries with undersea ecosystems with biological natural resources to seek to conserve the coral reefs. The efforts that have been made by the government are in the form of the arrangement of laws and regulations which are effective and have legal certainty. Bangladesh has no specific regulations for conservation or protection of coral reef ecosystem. Following the CTI, many countries have established regulations on coral reef protection based on international conventions and other regulations [4]. By creating such regulations, it shall make an effort to prevent, manage and conserve the coral reefs. 


\section{Materials and Methods}

\subsection{Study Area}

In Bangladesh, corals are found only on the Saint Martin (Narikel Jinjira) [5]. According to Warrick et al. (1993) the island is located on the eastern flank of an anticline and probably the part of Arakan-Naga folded system and therefore the island may be regarded as a sedimentary continental island whose coastal environment supports diverse coral communities. Saint Martin is a small island in the north-eastern part of the Bay of Bengal, around $9 \mathrm{~km}$ south of Cox's Bazar-Teknaf peninsular tip and forms the southernmost tip of Bangladesh shown in Figure 2. It lies approximately between $20^{\circ} 34^{\prime} \mathrm{N}-20^{\circ} 38.8^{\prime} \mathrm{N}$ and $92^{\circ} 18^{\prime}-$ $92^{\circ} 20.8^{\prime} \mathrm{E}[6]$.

\subsection{Methods}

This study was based on both Primary and secondary data. Primary data was collected to identify the threats of conservation and know the effectiveness of existing regulations to protect the bio-diversity of Saint Martin Island. Here primary data collection process followed field survey, Interviews with officials focus group discussion (FGD) of concerned selected area and environmentalists with arrangement of semi-structured questionnaire composition. This semi-structured questionnaire includes various types of questions regulating with legal provisions, conservations, waste management and tourism conditions.

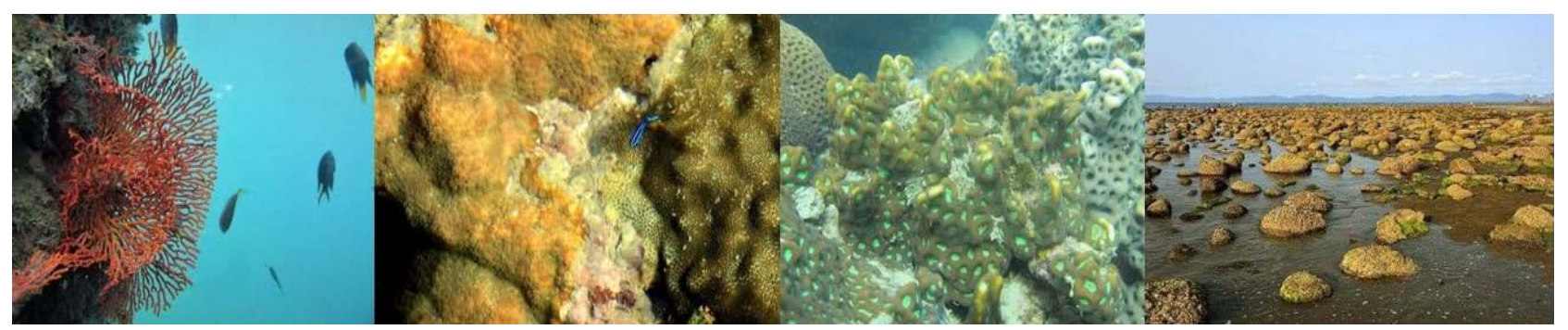

Figure 1. Corals of saint martin.
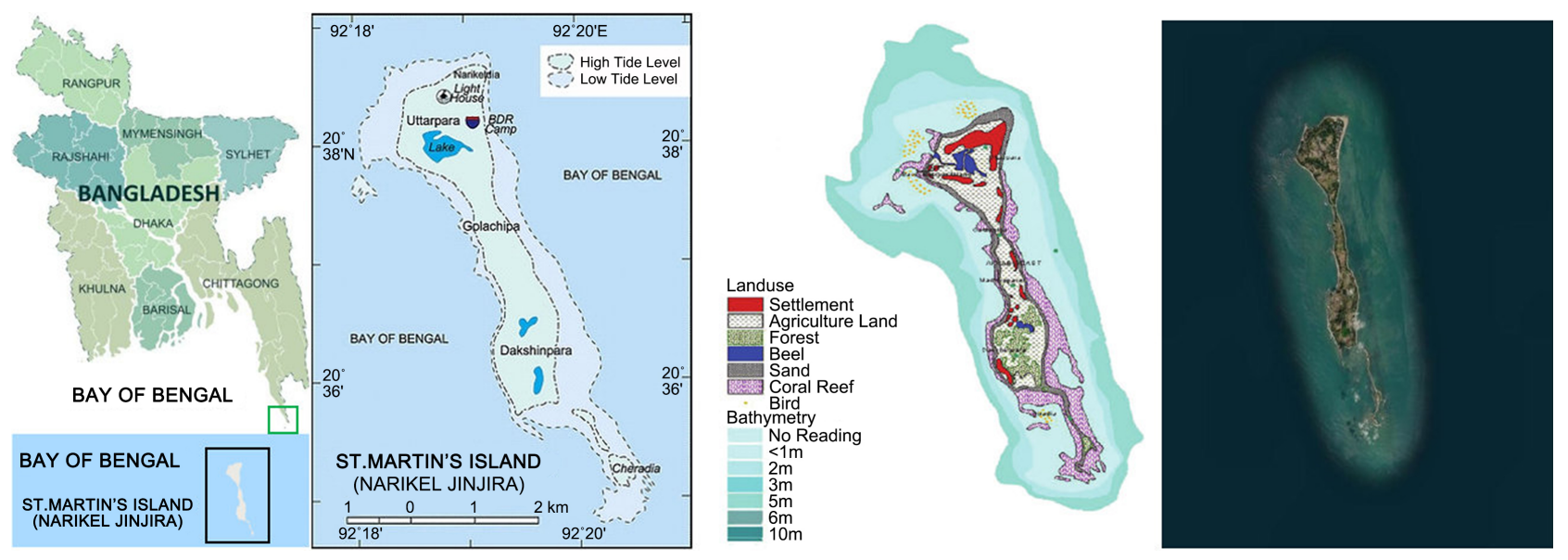

Figure 2. Saint Martin (Narikel Jinjira). 
On the other hand, secondary data will be collected through survey of various journals, law reports, statutory laws, ordinance, newspapers, rules and international instruments related to the research papers.

\section{Results}

Human activity has caused huge biodiversity loss in land and marine ecosystems all over the world, endangering many plant and animal species also [7]. There is no alternative to bring proper authority to scrutinize the local and global legal instruments for the better protection and conservation of marine ecosystem of Saint Martin Island.

\subsection{Environmental laws of Bangladesh Regulating Marine Resources}

National laws of Bangladesh are in process for the protection and conservation of marine resources in the coastal areas in Bangladesh [8]. According to the "Ecologically Critical Area Management Rules, 2016" conservation of marine resources is partly maintained in the Saint Martin Island. However no specific legal instrument is present to protect coral and coral reefs in Bangladesh [9]. Notwithstanding the Constitution of Bangladesh assured the natural resources bio-diversity, forests including wetlands for the present and future citizens. National laws, regulations and rules are described below.

\subsection{The Constitution of Bangladesh}

The Constitutions of People's Republic of Bangladesh has no specific provision on environment. Since The Constitution of Bangladesh was amended 17 times but only Article 18A of the constitution stated about guarantees to safeguard the natural habitats, biodiversity, wetlands, wildlife and forests for both present and future citizens and no further directions are added there [10].

\subsection{The Bangladesh Biodiversity Act 2017 (Act No. II)}

This Act was enacted to meet the obligations of the Constitution and the obligations of the CBD. This law indicates the goal of the CBD to promote the conservation of biodiversity, the sustainable use of its components with the proper and equitable sharing of benefits developing from the exercise of genetic resources. The Act regulates the biodiversity assessment and conservation through management committees from the village to the national level, preparation and periodical amendments of the biodiversity conservation strategy and planning and sharing of benefits arising from its components but no specific provisions were setup to any department for action plan, strategy, criminal activities or any activities [11]. However Bangladesh tourism board also excluded Maritime affairs unit from this Act. This law needs to implement strictly to conservation biodiversity, wildlife and the supervision of the concerned department to be strengthened. 


\subsection{Bangladesh Environment Conservation (ECA) Act, 1995 (Act 1 of 1995)}

This Act was passed for the conservation, improvement of environmental standard and control by reducing of the pollution in the environment. Afterwards, this Act has been amended many times. This law is closely connected to the Department of Environment, environment, pollution, occupant, environment pollutant, environment conservation, hazardous material, wastage, ecosystems and the Director General (DG) of that department [12]. Conservation as it has been stated in the Act of 1995 would require qualitative and quantitative improvement of various elements of the environment and prevention of its degradation. This Department of Environment also issues environment clearance certificate as well.

\subsection{The Bangladesh Environment Conservation (ECA) (Amendment) Act, 2010}

Further Amendments of this law regulates and stated new more definitions to various aspects of the main Act, such as: ecologically critical area, wetland, restriction on cutting hill hazardous waste, restriction on production, storage, import, loading and transportation of hazardous waste to protect the environment but this instrument did not describe the monocentric authority.

\subsection{The Environment Conservation Rules (ECR), 1997}

This act was enacted to exercise the powers conferred by section 20 of this act, which clearly stated that the declaration of ecologically critical area, procedure for issuing environmental clearance certificate, pollution under control certificate, determination of environmental standards, application relating to pollution or degradation of environment, procedure for hearing of appeal, various services and their fees etc. [13]. It sets The Environmental Quality Standards (EQS) to control quality of air, water, noise, emissions and discharge. Projects are categorized into four classes such as green, orange-a, orange-b and red according to their potential threat and impact to environment.

\subsection{The Environment Court Act, 2010 (Act No. 11 of 2000)}

This Act is aimed to establish one or more Environment Court/s in each district and to ensure proper justice against any social, economic and environmental damage. Besides the Environment Courts, Special Magistrates and Special Magistrate Courts are also given jurisdiction to exercise environmental cases. The Environment court has no suo moto jurisdiction or epistolary jurisdiction to take up an environmental cause and to exercise it [14]. Also the Court has a deficiency in governing the power of Judicial Review. According to the Section 5 sub-clause 3 of the Environmental Court Act 2000, it's stated: "No Environment Court shall take cognizance of an offense or receive any suit for compensation except on the written report of an Inspector or any other person authorized by 
the Director-General." Such complaining procedure is complex for the people. So, we can considerably say that the environmental court is more user friendly for the governmental ministry and more complex for the general people. The Environment Court's authority is not clear. Offenses and claims for compensation under the laws can be diverted by the Environment Court.

\subsection{Ecologically Critical Area Management Rules, 2016}

For the proper management and development of the ECAs, the Government framed the Ecologically Critical Areas (ECA) Management Rules, 2016 (hereafter the Rules). The Rules at first provide for the establishment of a National Committee consisting of a Chairperson and other members including academics and NGO activists. The Rules then describe responsibilities and functions of the National Committee. The National Committee plays a pivotal role in the management of ECAs [15]. It is this committee that is empowered, of its own accord, or on the basis of a request supported by information to the effect that due to environmental degradation the eco-system of an area is in a critical condition or is threatened to be in such situation, to recommend to government to declare an area as an ECA. In recommending a site, the National Committee will consider existing natural conditions and biodiversity, forests, wildlife, protected areas, wetlands etc. and causes for ecological degradation, possible threats and preventive measures for this. The National Committee will also make recommendations regarding the generation of alternative livelihoods for the people dependent on an ECA.

\subsection{The Wildlife (Conservation Security) Act 2012 (ACT NO. XXX OF 2012)}

The Government has enacted Wildlife Conservation Act 2012, which is very strict about wildlife related offences. According to wildlife (Security and Conservation) Act, 2012, wildlife includes any animal, aquatic and land vegetation, which forms part of any habitat [16]. So that, the term wildlife effectively encompasses whole forms of life, whether plant or animal which are found wild in nature. This would also include freshwater, marine and coastal ecosystems as well. This law is also called the umbrella legislation of Bangladesh.

\subsection{The Territorial Water and Maritime Zones Act 1974 (ACT NO. XXVI OF 1974)}

The Territorial Water and Maritime Zones Act, 1974 is the first legal instrument of the maritime boundary of Bangladesh. The law was framed in 1974 when there was no such a law in most of the countries in the world. This law indicates Territorial zone, Contiguous zone, Exclusive Economic zones (EEZ), Continental shelf, Conservation zone and control of the pollution and ecological balance from the territorial water zone to the high sea [17]. Since it was the first regulation regarding Maritime zones so that institutional arrangement is not visible in this Act. 


\subsection{Protection and Conservation of Fish Rules 1985}

Laws on Protection And Conservation Of Fish Rules, 1985 contains 11 sections regarding several measures of protection and conservation including 2 Schedules specifying that without a valid licence of catching certain fish is strictly illegal, specifying fish species of which the catching or sale in certain periods is illegal also bearing a form of a licence for catching of carps in Prohibited Waters. According to the law it is also stated that it is strictly prohibited of taking any type of attempt to destroy fish by pollution [18]. Overall aim of this Act is to protect freshwater fishing and prohibit any type of pollution of fishing.

\subsection{The State Acquisition and Tenancy Act 1950 (East Bengal Act) (ACT NO. XXVIII OF 1951)}

The act was mainly restoring the rights of owner whose land was eroded. It established a direct relationship between the state and the peasants through the acquisition of the rent-receiving interests of the intermediary groups. The law also fixed the limit of land-holding and empowered the government to acquire the surplus land [19]. This law clearly directed that cultivators can buy lands for non-bonafide cultivating but cannot purchase land for industrial or any commercial purposes without the proper consent of the authority.

\subsection{Protected Areas of Tourism and Particular Tourism Zone Act 2010 (ACT NO. 31 OF 2010)}

This law aims to manage, develop and develop the tourism industry and services sector in Bangladesh, enacting the creation of tourism protected areas and special tourism zones and the construction of unplanned structures in the areas of tourism and the control of activities [20]. It establishes the requirements to be met in order to perform tourism activity within protected reserve areas and special tourist zones.

\subsection{Ecological Critical Area Management Rules 2016}

The rules include provisions for the establishment of different Committees and also specify functions and responsibilities for these committees: the National Committee, the District Committee and the Upazilla Committee. Main purposes of making all these committees are to prohibit all types of pollution towards the natural resources on specific areas. These rules directed the legal basis for the management and co-management of ecologically critical areas and forest protected areas [21]. These Guidelines are aimed at improving the governance of wetlands and institutionalizing the dynamic participation of local communities and other stakeholders in managing these important bio-diverse areas.

\section{Barriers to Environmental Justice}

Whole world is facing an environmental problem-increasing of water pollution, air pollution, deforestation, climate change and other problems are threat- 
ening the existence of the world. To ensure effectual environmental justice, Bangladesh has a special court to cope with environmental issues by the Environment Court Act 2010. The approach to justice for ordinary people is not smooth in this court. Whereas, if anyone wants to file a case, they cannot do so directly [22]. One who wants to file case has to go to the Department of Environment (DOE) for the complaint and it is only after getting a report from a DOE authority, then the court can take the case. If the court is satisfied with the reasonability of the complaint then the court can directly take a case if the inspector or authority of DoE doesn't take proper steps within 60 days of the request of any individual. The whole process is complicated and also takes a long time with such barriers may discourage ordinary people from coming forth with environmental matters to the court to get proper environmental justice [23]. Since environmental crimes need scientific and technical knowledge, to give a judgment on such matters, it is important to have relevant knowledge regarding that. Sad to say, the judges of the ordinary court sit in the environment court but there is no specific environment expertise in the decision making procedure to aid them. The Act requires mentioning the expertise on environment with the training of judges specifically for environment court, those who will have scientific and technical knowledge specific to the environment issues. However, the court gives as a maximum penalty for an environmental offense is Taka 10 lakh under the Environment Conservation Act. Here, Penalties (which also include imprisonment) are very important to minimize this country's environmental issues but the fine may not be enough as most polluters are financially strong also the fine does not control them from committing the same offence in the future [24]. It is the high time that the Act needs to be reformed and provisions need to be modified which will make the court more friendly and accessible for the ordinary people to get environmental justice.

\section{Discussion}

Genuinely, the corals of Saint Martin Island are under threat. Most importantly the major threats are man-made. One of the noticeable reasons is ocean acidification to destroy coral reefs in many regions and corals of Saint Martin are not out of this. Water vessels are polluting the sea water with no proper mechanisms, unplanned construction works and building hotels and motels also destroying the eco system of Saint Martin Island, no proper rules and regulations are maintained here and plastic wastes of locals and tourists have brought threat to coral reefs, which is shown in Figure 3. Furthermore, directly use of coral of this island by the people is also one of the biggest threats to coral reefs [25]. This type of activities decreases the percent of the previous coral population of Saint Martin. It is the high time to make proper legal framework to protect coral reefs. Although a few rules and regulations are connected to conservation and protection of coral reefs again it is not adequate to protect Saint Martin coral reefs. Modification and reform of existing legal instruments are highly appreciated. 


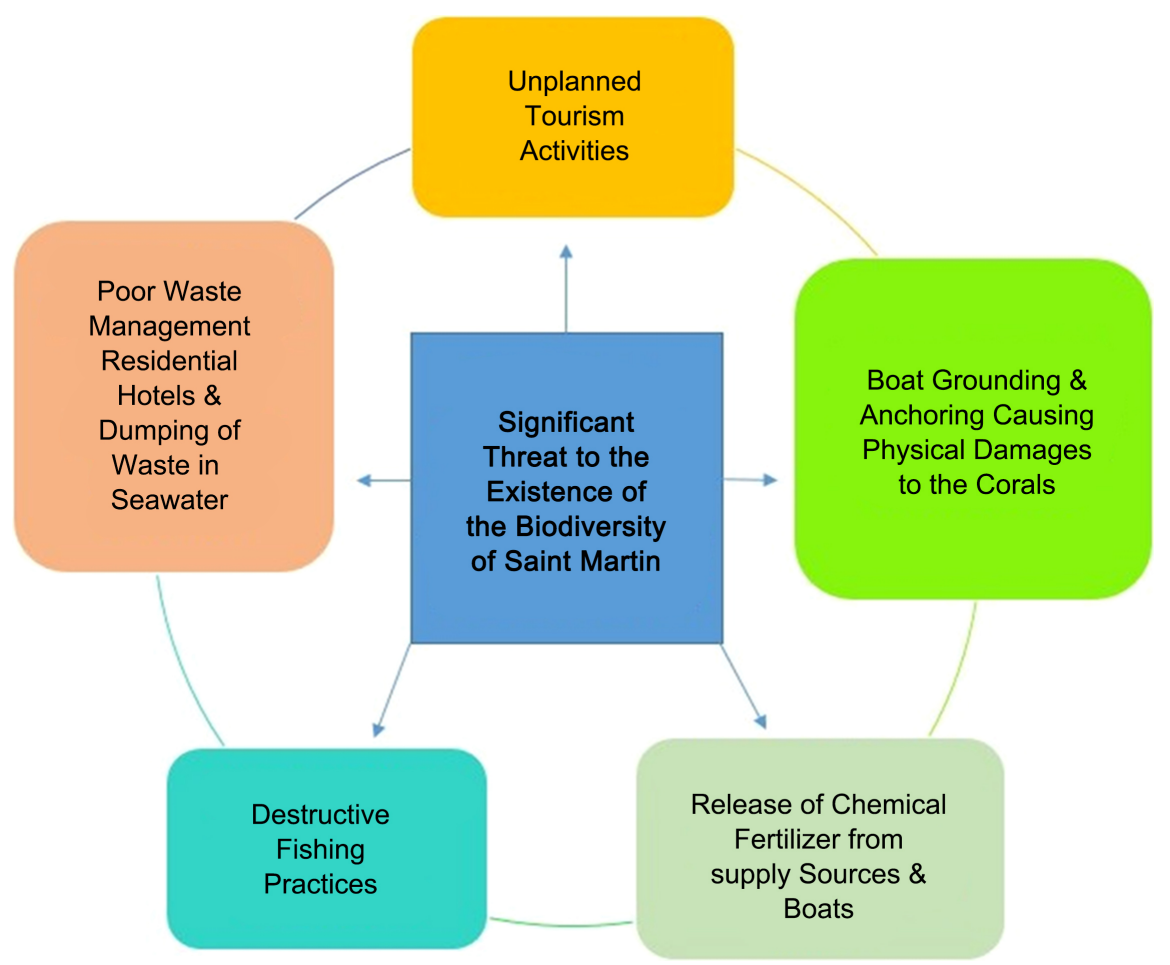

Figure 3. Significant threat to the existence of the biodiversity of St. Martin Island.

However, the main profession of the people of this island is fishing. The over-exploitation of fish over the coral bed and sailing ships and boat in this area has created an interaction gap between fish and coral, which jeopardizes the ecosystem of this area [26]. As Saint Martin is one of the most attractive tourist spots in Bangladesh, Every year a huge number of tourists visit this island. A huge number of tourists require a huge amount of food and enough residences as hotel and motels. The flourishing of residential hotels and restaurants create a huge amount of waste. Proper waste management must be done properly. Otherwise those wastes will go to the coral reefs and cause great harm to their ecosystem and growth. Government already marked Saint Martin Island as an ecologically critical area but still no proper measurements are visible to protect Saint Martin islands ecosystem as well.

A threat to the ecosystem is not a simple issue as long as a single interruption of food chain results in a massive disaster [27]. Sooner or later, Saint Martin will face an extreme disaster if we don't take diligent steps for protecting coral reefs from man made threats. So, our government should take essential and effective steps to save this one and only coral island of Bangladesh as early as possible.

\section{Recommendations}

Legal protection for coral reefs has begun worldwide and relatively recently in Bangladesh. In addition, existing protection consists of piecemeal laws, regulation, awareness and policies that serve either directly or indirectly to protect only certain coral reefs. By all biological accounts, coral reefs are at a crisis point in 
Bangladesh. However their preservation requires more coordinated measures to protect these treasures at the State and national level [28]. There are several way to get rid of this threat and protect the coral reefs of Saint Martin Island. However, some of the gaps identified towards improving the conservation of coral reefs in Bangladesh are as follows:

1) It is essential to classify the legal importance of biodiversity in coral reefs of Bangladesh so that the reef management runs within a proper legal boundary.

2) Determine the tourism area and protect Ecological Critical Area (ECA) with proper authorities will help the area for a balanced biodiversity.

3) Since people are going this area for tourism purposes so that many ships and boats sailed there continuously, for this reason it is mandatory to setup proper authority to stop sailing ships and boat in the coastal area.

4) There is no alternative of making awareness regarding coral reef ecosystem, wherefore arranging awareness campaign of pollution due to human-created threats to coral reefs is mandatory.

5) Prevention of all types of pesticides and chemical fertilizers in the coastal area is important because it creates pollutions in the Saint Martin Island.

6) Need to enforce the law regarding tourism and waste management of hotel and motels to reduce the pollution rate of the marine resources of this Ecological Critical Area (ECA) and also require a strong authority to monitoring these activities.

7) To cope up with the global legal framework to protect coral reefs it is important to modernizing national legal instruments with the references of global practices.

8) Ecologically Critical Area Management Rules, 2016 should be strictly followed for the conservation and protection of the biodiversity of the coral reefs in Saint Martin Island.

9) As stated in The Environment Court Act there is no sufficient number of environmental court and for smooth practice of environmental matters number of environmental court should increase and the mechanism of this court should be easy for ordinary people.

10) Government should pass an order and make it mandatory for the restaurant and hotel owners to recruit 20 percent of the local people at their hotels, which will help reduce poverty of the locals and prevent them from selling corals.

Still there may be time to save the biodiversity, corals, fish and marine resources of this island, otherwise it may be too late.

\section{Conclusions}

The biodiversity of St. Martin's island has global importance. Legal framework for protecting coral reefs and developing a clear government policy statement on the future conservation, management and protection objectives of marine resources is highly recommended. Rules, regulations and legal instruments with modernizing the framework are highly needed for establishing the Blue econo- 
my with proper sustainable coastal resources. According to the 15th Amendment of the Constitution Article 18A stated about the commitment of sustainable development and also command to protect and conservation of biodiversity.

Proper rules and regulations can bring a healthy ecosystem for coral reefs and also should take necessary steps to reserve Ecological Critical Area (ECA) like Saint Martin. It is the high time to take appropriate decisions to overcome global challenges such as ocean acidification of Bangladesh. Recognizing the legal importance of coral reefs will surely ensure healthy livelihood for the locals, promote ecotourism and maintain richness of the ecosystem.

\section{Conflicts of Interest}

The authors declare no conflicts of interest.

\section{References}

[1] Alam, O., Deng, T., Uddin, M. and Alamgir, M. (2015) Application of Environmental Ethics for Sustainable Development and Conservation of Saint Martins Island in Bangladesh. Journal of Environmental Science and Natural Resources, 8, 19-27. https://doi.org/10.3329/jesnr.v8i1.24628

[2] Shamsuzzaman, M.M. and Islam, M.M. (2018) Analysing the Legal Framework of Marine Living Resources Management in Bangladesh: Towards Achieving Sustainable Development Goal 14. Marine Policy, 87, 255-262. https://doi.org/10.1016/j.marpol.2017.10.026

[3] Farhad Hosen, M. (2019) An Overview of the Statutory Laws and Regulations Relating to the Maritime Issues of Bangladesh: Loopholes and Recommendations. Beijing Law Review, 10, 1331-1345. https://doi.org/10.4236/blr.2019.105071

[4] Mace, G.M., Norris, K. and Fitter, A.H. (2012) Biodiversity and Ecosystem Services: A Multilayered Relationship. Trends in Ecology \& Evolution, 27, 19-26. https://doi.org/10.1016/j.tree.2011.08.006

[5] Hasan, M.M. (2009) Tourism and Conservation of Biodiversity: A Case Study of St. Martins Island, Bangladesh. Law, Social Justice and Global Development Journal, 1, 14.

[6] Tamelander, J., Rajasuriya, A., Aquatic, N., Agency, D. and Zahir, H. (2008) Status of Coral Reefs in South Asia: Bangladesh, India, Maldives, Sri Lanka.

[7] Rabalais, N.N. (2002) Nitrogen in Aquatic Ecosystems. Ambio, 31, 102-112. https://doi.org/10.1579/0044-7447-31.2.102

[8] Ahammed, S.S., Hossain, M.A., Abedin, Z. and Khaleque, A. (2016) A Study of Environmental Impacts on the Coral Resources in the Vicinity of the Saint Martin Island, Bangladesh. International Journal of Scientific \& Technology Research, 5, 37-39.

[9] Sajal, I. (2018) Managing Ecologically Critical Areas in Bangladesh. IUCN Journal, 8, 65-72. https://file://C:/Users/HP/Downloads/IUCNAELeJournalISSUE865-72(1).pdf

[10] The Constitution of the People's Republic of Bangladesh. 18A. Protection and Improvement of Environment and Biodiversity. http://bdlaws.minlaw.gov.bd/act-367/section-41505.html

[11] Sajal, I.A. (2017) Bangladesh Biological Diversity Act 2017: An Appraisal. IUCNAEL E-Journal, 9, 132-141. 
[12] E. Conservation, et al. (2015) A Critical Appraisal of Bangladesh Environment Conservation Act, 1995 and Rules, 1997. 1-6.

[13] Ministry of Environment and Forest (2010) A Guide to Environmental Clearance Procedure. 1-16.

[14] Ullah, M.S. (2016) Greening Justice in Bangladesh: A Road to Successful Environmental Court. Green University Review of Social Sciences, 3, 101-128.

[15] (2019) Bangladesh: 6th National Report for the Convention on Biological Diversity. No. November, 133.

[16] FAO.org. http://www.fao.org/faolex/results/details/en/c/LEX-FAOC165019

[17] The Territorial Waters and Maritime Zones Act, 1974. http://bdlaws.minlaw.gov.bd/act-467.html

[18] The Protection and Conservation of Fish Act, 1950 (East Bengal Act). http://bdlaws.minlaw.gov.bd/act-details-233.html

[19] The State Acquisition and Tenancy Act, 1950 (East Bengal Act). http://bdlaws.minlaw.gov.bd/act-details-241.html

[20] Hossain, M.M. and Islam, M.H. (2006) Status of the Biodiversity of St. Martin's Island, Bay of Bengal, Bangladesh. Pakistan Journal of Marine Sciences, 15, 201-210.

[21] Conservation of ECAs. The Daily Star. https://www.thedailystar.net/law-our-rights/conservation-ecas-1415971

[22] The Effectiveness of Environment Courts. The Daily Star. https://www.thedailystar.net/law-our-rights/news/the-effectiveness-environment-co urts-1730299

[23] Revisiting Enforcement of Environment Court Act 2010-465878. https://www.daily-sun.com/printversion/details/465878/Revisiting-Enforcement-of-Environment-Court-Act-2010

[24] Weak Zone of the Environment Court Act, 2010 of Bangladesh. PDF. Magistrate. Lawsuit.

https://www.scribd.com/document/353842335/Weak-Zone-of-the-Environment-Co urt-Act-2010-of-Bangladesh

[25] Burke, L., Reytar, K., Spalding, M. and Perry, A. (2011) Reefs at Risk: Revisted.

[26] Côté, I.M. and Darling, E.S. (2010) Rethinking Ecosystem Resilience in the Face of Climate Change. PLOS Biology, 8, e1000438. https://doi.org/10.1371/journal.pbio.1000438

[27] Verlaan, P.A. (1991) South Asian Seas a Review of the Oceanography, Resources, and Environment.

[28] De'Ath, G., Fabricius, K.E., Sweatman, H. and Puotinen, M. (2012) The 27-Year Decline of Coral Cover on the Great Barrier Reef and Its Causes. Proceedings of the National Academy of Sciences of the United States of America, 109, 17995-17999. https://doi.org/10.1073/pnas.1208909109 